\title{
Biofertilizer as Prospective Input for Sustainable Agriculture in India
}

\author{
Manashi Barman ${ }^{*}$, Srijita Paul ${ }^{1}$, Aditi Guha Choudhury ${ }^{2}$, Pinaki Roy ${ }^{4}$ and Jahnavi $\operatorname{Sen}^{3}$ \\ ${ }^{1}$ Department of Agronomy, ${ }^{2}$ Department of Fruits and Orchard Management, ${ }^{3}$ Department of \\ Plant Physiology, Bidhan Chandra Krishi Viswavidyalaya, \\ Mohanpur, Nadia, West Bengal-741252, India \\ ${ }^{4}$ Division of Agricultural Extension, ICAR-IARI, New Delhi-110012, India \\ *Corresponding author
}

\section{A B S T R A C T}

The continuous increasing population in India leads huge pressure on agricultural lands along with other natural resources to produce more foods. Increasing use of chemical fertilizers in agriculture could make the country self-dependent in food production but on the contrary it deteriorates the environment and causes harmful impacts on living beings.

\section{Keywords}

Biofertilizer,

Microbes, Soil

fertility, Sustainable agriculture.

Article Info

Accepted:

10 September 2017

Available Online:

10 November 2017
During green revolution remarkable food production was noticed in which concern for sustainability was overlooked. Dependence on chemical fertilizers for future agricultural growth would mean further losses in soil quality and possibilities of water contamination. The term biofertilizer refers to formulation containing live microbes which helps in enhancing the soil fertility by fixing atmospheric nitrogen, solubilization of phosphorus and other nutrients and augmenting plant growth by producing growth hormones. Since the concept is not a new, multifarious advantages of biofertilizer leads to its wide applicability in sustainable agriculture. In spite of being cost effective and eco-friendly in nature, several constraints include unreliable supplies and absence of proper quality control limit the application or implementation of the technology. Extensive research is required to identify more suitable strains, develop better production technologies and quality control measures for wide commercialization of biofertilizer. The development of biofertilizer with multi-crop growth promoting activities is most important for sustainable global agriculture.

\section{Introduction}

The population in India as well as in the World is increasing day by day and it puts considering pressure on the agricultural lands and other resources to fulfill the need for food of this huge population. According to $15^{\text {th }}$ Census of India in 2011, the population is 121 million with decadal growth of $17.64 \%$ and around $68.84 \%$ of this is rural population. In case of Asia, it has been estimated that each $1 \%$ increment in crop productivity leads to
$0.48 \%$ reduction in number of poor people (Thirtle et al., 2003); while, in India 1\% rise in agricultural value added per hectare declines $0.4 \%$ poverty in the short run and $1.9 \%$ in the long run due to indirect effects of lower food prices and higher wages (Ravallion and Datt, 1996). Therefore, at present the most challenging issue is to increase the production of food from the rapidly shrinking per capita agricultural land 
(Bhattacharyya, 2009; Mazid and Khan, 2014). Generally, in conventional agriculture there are two major inputs necessary for crop production, viz., fertilizer and pesticide; in other words, it can be said that fertilizer is food and pesticide is medicine for plants (Muraleedharan et al., 2010). Though the production in India was remarkably high during periods of Green Revolution, poverty still remains as it was concentrated mainly in favorable areas.

Consequence of that, the growth of yield became downwards in addition to high utilization of chemical fertilizers caused poor soil health due to lack of organic matter, loss of inherent fertility (Mahajan and Gupta, 2009; Khare and Arora, 2015) by affecting soil micro flora and fauna (Gupta and Singh, 2008). Even it also impaired the health of human beings and animals (Gupta and Singh, 2006; Khare and Arora, 2015).

Moreover, plants cannot uptake all the nutrients applied through chemical fertilizers (Bhardwaj et al., 2014) so, some amount of nutrients are either fixed in the soil or leached out and ultimately mixed with water bodies (Mahdi et al., 2010). In order to make agriculture sustainable it is necessary to implement a balanced and reasonable use of nutrients which are cost effective and ecofriendly (Venkataraman and Shanmugasundaram, 1992; Mahdi et al., 2010); in that case biofertilizer could be a suitable option (Pindi and Satyanarayana, 2012; Borkar, 2015). Now, the Government of India has also taken a strideto harness the full potential of the available biofertilizers by introducing it along with chemical fertilizers to the farmers (Ghosh, 2004).

\section{Biofertilizer}

'Biofertilizer', also named as 'micro inoculants' (Arora et al., 2010), was derived from the retrenchment of the term 'biological fertilizer'; with biological, denoting the use of living organism or it can be defined as a product containing living microorganisms that colonizes in rhizosphere accompanying interior of the plant and stimulates growth by increasing the accessibility and uptake of mineral nutrients to the host plant (Vessey, 2003; Malusá et al., 2012; Malusá and Vassilev, 2014).

Biofertilizers can fix atmospheric nitrogen through the process of biological nitrogen fixation (BNF) and solubilize plant nutrients like phosphates, potash; in addition, it also stimulates plant growth through synthesis of different growth promoting substances and has $C$ : $N$ ratio 20:1 indicating its stability (Wani et al., 2013; Borkar, 2015). Biofertilizers can be categorized into five groups based on their nature and activity as follows (Table 1):

Recently, the potash mobilizers like Frateuri aaurentia, zinc and sulphur solubilizers like Thiobacillus sp. and manganese solubilizer fungal culture like Pencillium citrinum have also been identified for commercial operations (Borkar, 2015).

\section{History of biofertilizer use in India}

In India, systematic study on biofertilizers was started by N. V. Joshi in 1920. Rhizobium was the first isolated from various cultivated legumes and this was followed by extensive research by Gangulee, Sarkaria and Madhok on the physiology of the nodule bacteria along with its inoculation for better crop production (Panda, 2011). The milestones in research, production and promotion of biofertilizer in India are given in table 2.

Now, Rhizobium and Blue Green Algae (BGA) can be considered as established biofertilizers whereas Azolla, Azospirillum 
and Azotobacter are at an intermediate stage (Panda, 2011).

\section{Practical significance of biofertilizer}

Biofertilizers make nutrients available that are naturally abundant in soil and atmosphere to plants. Various field studies have demonstrated these to be effective and cheap inputs, free from any environmental hazards (Ghosh, 2004; Sahoo et al., 2014; Borkar, 2015). In a nutshell, it provides "ecofriendly" organic agro-input which has the ability to convert nutritionally important elements from unavailable to available form through biological processes (Vessey, 2003). So, it can be expected to reduce the use of chemical fertilizers and pesticides by introducing biofertilizers (Subashini et al., 2007). The microorganisms in biofertilizers reestablish natural nutrient cycle, maintain optimum nutrient level in soil and also increase soil organic matter content as a result healthy plants can be grown, while upholding sustainability and fertility of the soil (Singh et al., 2011; Sinha et al., 2014; Shelat et al., 2017). Therefore, they are extremely advantageous in enriching soil fertility and fulfilling plant nutrient requirements by supplying organic nutrients. Besides accessing nutrients for current intake as well as residual, different biofertilizers provide growth-promoting factors to plants through secretion of different vitamins, phytohormones (Revillas et al., 2000; Abd ElFattah et al., 2013) and by successfully facilitating composting and controlling attack of pest and soil borne diseases (Board, 2004; Sinha et al., 2014). It not only saves chemical fertilizers but also help in its effective utilization and results in higher yield rates (Ghosh, 2004).

Dryland agriculture constitutes a very large part of agricultural area in India including majority of the poor people and more than $90 \%$ of coarse cereals, $80 \%$ of groundnut and $85 \%$ of pulses come from these regions
(Ghosh, 2004). Dryland agriculture is characterized by low productivity, unpredictable climatic swings and low dosage of chemical fertilizers and in this situation biofertilizers, particularly Rhizobium, could be a bridge between removals and additions to soil nutrients where farmers can scarcely afford costly inputs (Das et al., 2015).

It is an established fact that due to fixation in acidic and alkaline soils, the efficiency of phosphatic fertilizers is very low (15-20\%) and unfortunately both soil types are prevailing in India (Board, 2004).

On that account, the inoculation of phosphate solubilizing bacteria in soils is needed to restore and maintain the effective microbial populations for solubilization of chemically fixed phosphorus as well as availability of other macro and micronutrients to harvest good sustainable yield of various crops (Mahdi et al., 2010).

\section{Marketed biofertilizers in India}

The following types of microorganisms as biofertilizers are available to the farmers in India:

Nitrogen fixer, e.g. Rhizobium, Bradyrhizobium, Azospirillum, Azotobacter, Acetobacter, Azolla and BGA.

Phosphorus solubilizer, e.g. Bacillus, Pseudomonas and Aspergillus.

Phosphate mobilizer, e.g. VA-mycorrhiza (VAM) like Glomus.

K-solubilizer, e.g. Frateuria aurantia.

Silicate solubilzer, e.g. Thiobacillus thiooxidans.

Plant growth promoting biofertilizers, e.g. Pseudomonas sp. (Muraleedharan, 2010; Mishra and Arora, 2016). 


\section{Production scenario in India}

Estimated annual requirement of Rhizobium inoculum varies from 1,250 to $15,000 t$ (Panda, 2011). The highest requirements of biofertilizers can be quantified through an over-simplified approach multiplying the total legume area by dosage per hectare; therefore if $25 \%$ of area is annually treated, 3750t inoculum is needed for $30 \mathrm{mha}$ and the present production is about one-fourth of this. Year wise (2008-09 to 2014-15) production in India has been listed in table 3. Based on crop area in India, the present requirement of biofertilizers is around 5,50,000 metric tonnes and there is an ample potential to increase it to $50,000-60,000$ tons by 2020 (Pindi and Satyanarayana, 2012); however, the total production in our country is much less than requirement which points out the inevitability of increase in biofertilizer production.

Now, the government of India is boosting the biofertilizer industries by providing subsidies to a maximum of 20 lakh rupees and awarding a national productivity award to the efficient biofertilizer production unit (Borkar, 2015). Agro Industries Corporation has the maximum production capacity which is followed by State Agriculture Departments, National Biofertilizers Development Centers, State Agricultural universities and private sectors (Pindi and Satyanarayana, 2012).

\section{Reasons behind little popularization of biofertilizer in India}

Despite the multiple advantages of biofertilizer in agricultural production, several constraints at different levels i.e. from production unit to farmers' field are there for making it less popular in India.

\section{Production and distribution level}

Generally, activity of microorganisms are location and crop specific so, strains selected for particular areas as well as crops should have good adaptability for this specific location and some qualities like competitive ability over other strains for nodulation of host, N-fixing ability, potentiality to colonize and survive in adverse physical conditions (Panda, 2013).

Some biofertilizer production units do not have sufficient technically well-qualified microbiologist or skilled persons who can make available high quality biofertilizers rather depend on more of non-skilled labours working on contract basis that leads to substandard biofertilizers (Mahdi et al., 2010; Mathur et al., 2010; Motghare and Gauraha, 2012). In addition, non-availability of good quality peat in India has also headed to the development of alternative carriers like, lignite, charcoal, etc. which are mostly used unsterilized (Borkar, 2015; Panda, 2013).Most studies suggest that biofertilizers, sold in markets are contaminated and have a low count of microorganisms. Generally, producers do not pay attention to the host specific strains and as a result biofertilizers cannot express their potentiality (Mazid and Khan, 2014; Motghare and Gauraha, 2012). Indian Standard Institute (ISI) specifications are recently available only for Rhizobium and Azotobacter; specification for Azospirillum and phosphobacteria have been formulated. Till now, there is no regulatory act for production of biofertilizers (Mazid and Khan, 2014).

\section{Storage and distribution level}

Successful introduction of biofertilizers in farmers' field is still limited to certain crops and locations, either because of environmental or biological factors i.e. soilRhizobium-plant relationship (Panda, 2013). As biofertilizers are live microorganisms, usually dies or loss their activity in case of temperature fluctuation. 
Table.1 Different groups of biofertilizers

\begin{tabular}{|c|c|c|}
\hline Sl. No. & Groups & Examples \\
\hline \multicolumn{3}{|c|}{ 1. Nitrogen $\left(\mathrm{N}_{2}\right)$ fixing Biofertilizers } \\
\hline I & Free-living & Azotobacter, Clostridium, Anabaena, Nostoc \\
\hline Ii & Symbiotic & Rhizobium, Frankia, Anabaena azollae \\
\hline Iii & Associative Symbiotic & Azospirillum \\
\hline \multicolumn{3}{|c|}{ 2. P-Solubilizing Biofertilizers } \\
\hline I & Bacteria & $\begin{array}{l}\text { Bacillus megaterium var. phosphaticum, } \\
\text { Bacillus circulans, Pseudomonas striata }\end{array}$ \\
\hline Ii & Fungi & Penicillium sp., Aspergillus awamori \\
\hline \multicolumn{3}{|c|}{ 3. P-Mobilizing Biofertilizers } \\
\hline I & Arbuscular mycorrhiza & $\begin{array}{l}\text { Glomus sp., Gigaspora sp., Acaulospora sp., } \\
\text { Scutellospora sp., Sclerocystis sp. }\end{array}$ \\
\hline Ii & Ectomycorrhiza & Laccaria sp., Pisolithus sp., Boletus sp., Amanita sp. \\
\hline Iii & Orchid mycorrhiza & Rhizoctonia solani \\
\hline \multicolumn{3}{|c|}{ 4. Biofertilizers for Micro nutrients } \\
\hline I & Silicate and zinc solubilizers & Bacillus sp. \\
\hline \multicolumn{3}{|c|}{ 5. Plant Growth Promoting Rhizobacteria } \\
\hline $\mathbf{I}$ & Pseudomonas & Pseudomonas fluorescens \\
\hline
\end{tabular}

Source: Biofertilizers- types and their application, KrishiSewa

Table.2 Some milestones in research, production and promotion of biofertilizer in India

\begin{tabular}{|l|l|}
\hline \multicolumn{1}{|c|}{ Year } & \multicolumn{1}{c|}{ Events } \\
\hline 1920 & First study on Legume-Rhizobium symbiosis by N. V. Joshi. \\
\hline 1934 & Earliest documented production of Rhizobium inoculant by M. R. Madhok. \\
\hline 1939 & Discovery of nitrogen fixation by Blue Green Algea (BGA) in rice field by P. K. Dey. \\
\hline 1939 & Report on performance of Azotobacter in rice soil by B. N. Uppal. \\
\hline 1956 & First commercial production of biofertilizer. \\
\hline 1957 & Study on solubilization of phosphate by microorganisms by Sen and Pal. \\
\hline 1958 & First attempt to standardize quality of legume inoculant by A. Sankaran. \\
\hline 1960 & $\begin{array}{l}\text { First isolation of new non-symbiotic N-fixing organism Derxiagummosa in the world by P. K. Dey and } \\
\text { R. Bhattacharyya. }\end{array}$ \\
\hline 1964 & Spurt in demand of biofertilizer for soybean particularly in Madhya Pradesh. \\
\hline 1968 & $\begin{array}{l}\text { All India Pulse Improvement Project and Soybean Project set up by ICAR where Rhizobium study got } \\
\text { priority. }\end{array}$ \\
\hline 1969 & Use of Indian peat as carrier reported by V. Iswaran. \\
\hline 1975 & Coal as alternate carrier to peat reported by J. N. Dube. \\
\hline 1976 & Indian Standard Specification for Rhizobium. \\
\hline 1977 & Use of ISI mark for Rhizobium. \\
\hline 1979 & Initiation of All India Coordinated Project on BNF. \\
\hline 1979 & ISI standard for Azotobacter inoculant. \\
\hline 1983 & $\begin{array}{l}\text { Setting up of National Project on Development and use of Biofertilizer by Ministry of Agriculture, } \\
\text { Govt. of India. }\end{array}$ \\
\hline 1985 & First National Productivity award on Biofertilizer. \\
\hline 1988 & Setting up of National Facility Centre for BGA at IARI. \\
\hline
\end{tabular}

Source: Panda, 2011 
Table.3 Year wise biofertilizer production (in tonnes) in India

\begin{tabular}{|c|c|c|c|c|c|c|c|}
\hline \multirow{2}{*}{ Name of the State } & \multicolumn{7}{|c|}{ Year } \\
\hline & 2008-09 & 2009-10 & $2010-11$ & 2011-12 & $2012-13$ & 2013-14 & 2014-15 \\
\hline \multicolumn{8}{|l|}{ South Zone } \\
\hline Andhra Pradesh & 168.136 & 1345.28 & 999.60 & 1126.35 & 1335.74 & 2714.22 & 2668.80 \\
\hline Karnataka & 11921.057 & 3695.50 & 6930.00 & 5760.32 & 7683.72 & 9907.34 & 16462.62 \\
\hline Kerala & 1187.001 & 1936.45 & 3257.00 & 904.17 & 1045.64 & 3520.66 & 4916.97 \\
\hline Pondicherry & 561.7924 & 452.79 & 783.00 & 509.45 & 621.00 & 516.98 & 560.95 \\
\hline Tamil Nadu & 4687.818 & 3732.59 & 8691.00 & 3373.81 & 11575.70 & 14104.8 & 15373.29 \\
\hline Total & $\mathbf{1 8 5 2 5 . 8 0 4}$ & 11162.61 & 20660.60 & 11674.10 & 22261.80 & 30764.03 & 39982.63 \\
\hline \multicolumn{8}{|l|}{ West Zone } \\
\hline Chhattisgarh & 0.00 & 0.00 & 0.00 & 276.34 & 501.63 & 712.07 & 1024.68 \\
\hline Gujarat & 1149.695 & 1309.19 & 6318.00 & 2037.35 & 978.48 & 6411.434 & 3667.929 \\
\hline Goa & 0.00 & 0.00 & 443.40 & 0.00 & 370.00 & 66.26 & 802.52 \\
\hline Madhya Pradesh & 848.448 & 1587.68 & 2455.57 & 2309.06 & 1408.08 & 4824.194 & 2637.99 \\
\hline Maharashtra & 1249.87 & 1861.33 & 2924.00 & 8743.69 & 5897.91 & 6218.607 & 14847.397 \\
\hline Rajasthan & 353.67 & 805.57 & 819.75 & 199.78 & 982.00 & 1315.00 & 599.898 \\
\hline Total & 3601.683 & $\mathbf{5 5 6 3 . 7 7}$ & 12960.72 & 13566.22 & 10138.10 & 19547.565 & 23580.414 \\
\hline \multicolumn{8}{|l|}{ North Zone } \\
\hline Delhi & 1165.1 & 1021.85 & 1205.00 & 1617.00 & 0.00 & 396.00 & 104.50 \\
\hline Chandigarh & 0.00 & 0.00 & 0.00 & 0.00 & 0.00 & 1146.483 & 872.955 \\
\hline Haryana & 14.25 & 6.20 & 6.53 & 914.41 & 5832.61 & 26.147 & 0.768 \\
\hline Himachal Pradesh & 0.00 & 8.50 & 9.00 & 1.29 & 0.00 & 45.26 & 0.00 \\
\hline Punjab & 1.14 & 301.23 & 2.50 & 692.22 & 2311.33 & 2124.85 & 6305.453 \\
\hline Uttar Pradesh & 885.5174 & 962.64 & 1217.45 & 8695.08 & 1310.02 & 2682.27 & 4099.068 \\
\hline Uttarakhand & 48.23 & 32.00 & 45.00 & 263.01 & 2758.21 & 5493.85 & 2129.952 \\
\hline Total & 2114.2374 & 2332.42 & 2485.48 & 12183.01 & 12212.17 & 11914.86 & 13512.696 \\
\hline \multicolumn{8}{|l|}{ East Zone } \\
\hline Bihar & 0.00 & 0.00 & 136.26 & 75.00 & 52.40 & 52.40 & 64.90 \\
\hline Jharkhand & 15.00 & 15.00 & 0.00 & 8.38 & 35.30 & 14.20 & 9.08 \\
\hline Odisha & 405.03 & 289.87 & 357.66 & 590.12 & 407.10 & 1097.61 & 1074.46 \\
\hline West Bengal & 241.24 & 256.50 & 393.39 & 603.20 & 1110.00 & 1682.71 & 2061.83 \\
\hline Total & 661.27 & 561.37 & 887.31 & 1276.70 & 1604.80 & 2846.92 & 3210.27 \\
\hline \multicolumn{8}{|l|}{ North East Zone } \\
\hline Arunachal Pradesh & 0.00 & 0.00 & 0.00 & 0.00 & 0.00 & 59.00 & 59.0 \\
\hline Assam & 129.3552 & 121.04 & 130.00 & 68.33 & 89.00 & 149.00 & 88.0 \\
\hline Mizoram & 1.996 & 2.50 & 2.00 & 0.00 & 0.00 & 4.00 & 3.60 \\
\hline Nagaland & 16.0092 & 18.25 & 21.50 & 13.00 & 7.45 & 7.45 & 7.45 \\
\hline Sikkim & 0.00 & 0.00 & 0.00 & 0.00 & 9.50 & 10.10 & 12.40 \\
\hline Tripura & 14.68 & 278.40 & 850.00 & 1542.85 & 514.00 & 225.00 & 240.0 \\
\hline Total & 162.0404 & 420.19 & 1003.50 & 1624.18 & 619.95 & 454.55 & 410.45 \\
\hline Grand Total & 25065.035 & 20040.36 & 37997.61 & 40324.21 & 46836.82 & 65527.87 & 80696.46 \\
\hline
\end{tabular}

Source: National Centre of Organic Farming, Department of Agriculture \& Cooperation (DAC) (2013, 2014 and 2015)

Such situations occur frequently while biofertilizer containing packets are delivered from production units to sowing fields (Mathur et al., 2010). There is also lack of knowledge about the storage condition among the farmers for which actual potential of biofertilizers are not explored and sometimes farmers' are unwilling to use (Panda, 2013). Besides this, in most of the cases, proper storage conditions for the inoculants are not available at each point in the distribution chain (Motghare and Gauraha, 2012). 


\section{Field level}

Most of the farmers in India do not have enough perception on the use of biofertilizer. Similarly, low level of acceptance of it at farmers' level is due to slow response as compared to chemical fertilizers. Some biofertilizers are crop as well as location specific; therefore its efficacy does not remain same at different locations due to difference in agro-climatic conditions and soil edaphic factors (Panda, 2013). In addition, there is no facility of foretasting and also no extension and propaganda of biofertilizers is being undertaken on large scale (Borkar, 2015).

Moreover, the activities of microorganisms vary with the chemical properties of soil so, highly acidic as well as saline soils adversely affect the population of introduceed biofertilizer (Fierer and Jackson, 2006). Sometimes in soils where $\mathrm{P}$ availability is less, the nitrogen-fixing biofertilizer does not function effectively (Khare and Arora, 2015). Therefore, soil amendments and chemical fertilizations are essential in these situations.

\section{Market level}

Marketing of biofertilizers is troublesome as the product contains living organisms with restricted shelf life (Motghare and Gauraha, 2012), only six months in powder form as a result, it is difficult under Indian conditions to transport, store and distribute the material in time. Besides this, there is no standardization in packing, labeling and prices of biofertilizers (Das et al., 2015).

Sometimes, when packets arrive in villages, they are either spoiled or over dated; therefore, they become useless because organisms contained in biofertilizers die very quickly (Borkar, 2015).

Furthermore, different state governments sometimes provide subsidies up to $50 \%$ of the sales but the manner of subsidization is rather unsystematic even in many cases discrimination and manipulation in subsidizing lead to a lot of intra industry variation in prices (Ghosh, 2004).

\section{Liquid biofertilizers - A step forward to biofertilizer technology}

Liquid biofertilizers are suspension containing desired microorganisms and special cell protectants or chemicals that encourage formation of latent spores or cysts for longer shelf life and tolerance to adverse environments (Hegde, 2008). The advantages of liquid biofertilizers over powder based are that microorganisms have longer shelf life upto 2 years, generally they circumvent the effect of high temperature, maintain high $c f u$ more than $10^{9} \mathrm{ml}^{-1}$ upto 12 months and better survive on seeds and soil, in addition, liquid biofertilizers are easy to use, handling and storage by farmers, the dosage is ten times less than that of powder form, it can be packed in different volumes and save carrier materials (Verma et al., 2011; Borkar, 2015).

Biofertilizers have potential role in sustainable agriculture; these can be used along with chemical fertilizers to enhance the soil fertility and crop yield. In India, farmers' specially marginal farmers can get more profit from the same size of land by using biofertilizers instead of application of chemical fertilizers alone. However, most farmers are not aware of it; therefore, to popularize this technology training should be provided to the farmers and this can be done through demonstration trials on the cultivator's fields. In this case, extension workers would play an important role. Moreover, more researches are needed to identify crop and location specific microbial strains with higher efficacy. The government should introduce strict law and policy against 
the quality of biofertilizers so that farmers can get benefits of this technology.

\section{References}

Abd El-Fattah, D.A., Ewedab, W.E., Zayed, M.S. and Hassaneina, M.K. 2013.Effect of carrier materials, sterilization method, and storage temperature on survival and biological activities of Azotobacter chroococcum inoculants. Annals of Agricultural Sciences. 58(2): 111-118. doi: 10.1016/j.aoas.2013.07. 001

Arora, N.K., Khare, E. and Maheshwari, D.K. 2010. Plant growth promoting rhizobacteria: constraints in bioformulation, commercialization, and future strategies In: Plant growth and health promoting bacteria (Eds.) D.K. Maheshwari. Springer-Verlag, Berlin. Pp. 97-116.

Bhardwaj, D., Ansari, M.W., Sahoo, R.K. and Tuteja, N. 2014. Biofertilizers function as key player in sustainable agriculture by improving soil fertility, plant tolerance and crop productivity. Microbial Cell Factories. 13: 66. doi: 10.1186/1475-2859-13-66

Bhattacharyya, P. 2009. Use of Biotechnology tools in biofertilizer production In: A Textbook of Molecular Biotechnology. I. K. International Pvt. Ltd. Pp.659-676.

Board, N.I.I.R. 2004. The Complete Technology Book on Bio-Fertilizer and Organic Farming. National Institute of Industrial Re.

Borkar, S.G. 2015. Microbes as Biofertilizers and Their Production Technology. Wood head Publishing India Pvt. Ltd., New Delhi, India.Pp.7-153.

Census of India 2011. Rural Urban Distribution Of Population, Census of India 2011 (Provisional Population Totals), Chandramouli, C. Registrar
General \& Census Commissioner, India Ministry of Home Affairs. http://censusindia.gov.in/2011-provresults/ paper2/data_files/india/Rural_ Urban_2011.pdf

Das, D., Dwivedi, B.S., Meena, M.C.,Singh, V.K. and Tiwari, K.N. 2015. Integrated Nutrient Management for Improving Soil Health and Crop Productivity.Indian Journal of Fertilizers.11(4): 64-83.

Fierer, N. and Jackson, R.B. 2006.The diversity and biogeography of soil bacterial communities.Proceedings of the National Academy of Sciences. 103(3): 626-631. doi: 10.1073/pnas. 0507535103

Ghosh, N. 2004.Promoting biofertilisers in Indian agriculture. Econ Polit Wkly. 5: 5617-5625.

Gupta, R.D. and Singh, H. 2006. Indiscriminate use of fertilizer poses health hazards. Farmer's Forum. 9(6): $20-24$.

Gupta, R.D. and Singh, H. 2008. Indiscriminate use of pesticides in agriculture: Public health issues and their control. Indian Farmers' Digest. 41(1): 8-13.

Hegde, S.V. 2008.Liquid bio-fertilizers in Indian agriculture. Bio-fertilizer newsletter. Pp. 17-22.

Khare, E. and Arora, N.K. 2015. Effects of soil environment on field efficacy of microbial inoculants In: Plant Microbes Symbiosis: Applied Facets (Eds.) N.K. Arora. Springer, India. Pp. 37-75.

Mahajan, A. and Gupta, R.D. 2009. Biofertilizers: their kinds and requirement in India In: Integrated Nutrient Management (INM) in a Sustainable Rice-Wheat Cropping System. Springer, Netherlands. Pp. 75100. doi:10.1007/978-1-4020-9875-8

Mahdi, S.S., Hassan, G.I., Samoon, S.A., Rather, H.A., Dar, S.A. and Zehra, B. 
2010.Bio-fertilizers in organic agriculture. Journal of Phytology. 2(10): 42-54.

Malusá, E. and Vassilev, N. 2014.A contribution to set a legal framework for biofertilisers. Applied Microbiology and Biotechnology. 98(15): 6599-6607. doi: 10.1007/s00253-014-5828-y.

Malusa, E., Sas-Paszt, L. and Ciesielska, J. 2012. Technologies for beneficial microorganisms inocula used as biofertilizers. The Scientific World Journal. ID. 491206doi:10.1100/2012/491206

Mathur, N., Singh, J., Bohra, S., Bohra, A. and Vyas, A. 2010. Microbes as Biofertilizers In: Cellular and Biochemical Science (Eds.) G. Tripathi. I. K. International Pvt. Ltd. Pp.10891113.

Mazid, M. and Khan, T.A. 2014. Future of Bio-fertilizers in Indian Agriculture: An Overview, International Journal of Agricultural and Food Research. 3(3): 10-23.

Mishra, J. and Arora, N.K. 2016.Bioformulations for Plant Growth Promotion and Combating Phytopathogens: A Sustainable Approach In: Bioformulations: for Sustainable Agriculture (Eds.) N.K. Arora, S. Mehnaz and R. Balestrini. Springer, India. Pp. 3-33. doi: 10.1007/978-81-322-2779-3_1

Motghare, H. and Gauraha, R. 2012.Biofertilizers- types and their application, KrishiSewa. http://www. krishisewa.com/articles/organicagriculture/115-biofertilizers.html

Muraleedharan, H., Seshadri, S. and Perumal, K. 2010. Biofertilizer (Phosphobacteria), Booklet published by Shri AMM Murugappa Chettiar Research Centre, Taramani, Chennai600113.

National Centre of Organic Farming,
Department of Agriculture \& Cooperation (DAC), Indian Fertilizer Scenario 2013, Department of Fertilizers, Ministry of Chemicals and Fertilizers, Government of India.

National Centre of Organic Farming, Department of Agriculture \& Cooperation (DAC), Indian Fertilizer Scenario 2014, Department of Fertilizers, Ministry of Chemicals and Fertilizers, Government of India.

National Centre of Organic Farming, Department of Agriculture \& Cooperation (DAC), Indian Fertilizer Scenario 2015, Department of Fertilizers, Ministry of Chemicals and Fertilizers, Government of India.

Panda, H. 2011.Manufacture of Biofertilizer and Organic Farming. Asia Pacific Business Press Inc. Pp. 103-121.

Panda, H. 2013.Handbook on Organic Farming and Processing.Asia Pacific Business Press Inc. Pp. 149-152.

Pindi, P.K. and Satyanarayana, S.D.V. 2012.Liquid Microbial Consortium- A Potential Tool for Sustainable Soil Health. Journal of Biofertilizers \&Biopesticides. 3(4): 124 . doi: 10.4172/2155-6202.1000124

Ravallion, M. and Datt, G. 1996. How important to India's poor is the sectoral composition of economic growth? World Bank Econ Rev. 10: 125.

Revillas, J.J., Rodelas, B., Pozo, C., MartinezToledo, M.V. and Gonzalez, L.J. 2000.Production of B-Group vitamins by two Azotobacter strains with phenolic compounds as sole carbon source under diazotrophic and adiazotrophic conditions. Journal of Applied Microbiology. 89: 486-493. doi: 10.1046/j.1365-2672.2000.01139.x

Sahoo, R.K., Ansari, M.W., Pradhan, M., Dangar, T.K., Mohanty, S. and Tuteja, N. 2014. Phenotypic and molecular 
characterization of efficient native Azospirillum strains from rice fields for crop improvement. Protoplasma. 251(4): 943-953. doi: 10.1007/s00709013-0607-7

Shelat, H.N., Vyas, R.V. and Jhala, Y.K. 2017. Biofertilizers and PGPR for evergreen agriculture In: Microorganisms in Sustainable Agriculture, Food and the Environment (Eds.) D.K. Verma and P.P. Srivastav. CRC Press, Taylor \& Francis Group.

Singh, J.S., Pandey, V.C. and Singh, D.P. 2011. Efficient soil microorganisms: a new dimension for sustainable agriculture and environmental development. Agric Ecosyst Environ. 40: 339-353. doi: 10.1016/j.agee.2011. 01.017

Sinha, R.K., Valani, D., Chauhan, K. and Agarwal, S. 2014. Embarking on a second green revolution for sustainable agriculture by vermiculture biotechnology using earthworms: reviving the dreams of Sir Charles Darwin. Int J Agric Health Saf. 1: 50 64

Subashini, H.D., Malarvannan, S. and Kumar, P. 2007. Effect of biofertilizers on yield of rice cultivars in Pondicherry, India.
Asian Journal of Agriculture Research. 1(3): 146-150. doi: 10.3923/ ajar.2007.146.150

Thirtle, C., Lin, L. and Piesse, J. 2003. The impact of research-led agricultural productivity growth on poverty reduction in Africa, Asia and Latin America. World Dev. 31: 1959-1975.

Venkataraman, G.S. and Shanmugasundaram, S. 1992. Algal biofertilizers technology for rice.DBT Centre for BGA. Biofertilizer, Madurai Kamraj University, Madurai, 625021, T.N.

Verma, M., Sharma, S. and Prasad, R. 2011. Liquid Biofertilizers: Advantages Over Carrier Based Biofertilizers for Sustainable Crop Production. International Society of Environmental Botanists.17(2).

Vessey, J.K. 2003.Plant growth promoting rhizobacteria as biofertilizers. Plant and Soil. 255(2): 571-586. doi: 10.1023/A: 1026037216893.

Wani, S.A., Chand, S. and Ali, T. 2013. Potential Use of Azotobacter chroococcum in Crop Production: An Overview. Current Agriculture Research Journal.1 (1): 35-38. doi: 10.12944/CARJ.1.1.04

\section{How to cite this article:}

Manashi Barman, Srijita Paul, Aditi Guha Choudhury, Pinaki Roy and Jahnavi Sen. 2017. Biofertilizer as Prospective Input for Sustainable Agriculture in India. Int.J.Curr.Microbiol.App.Sci. 6(11): 1177-1186. doi: https://doi.org/10.20546/ijcmas.2017.611.141 